\title{
TGF-beta-Resistant LMP-Specific Cytotoxic T-Lymphocytes
}

National Cancer Institute

\section{Source}

National Cancer Institute. TGF-beta-Resistant LMP-Specific Cytotoxic T-Lymphocytes. NCl Thesaurus. Code C77859.

A preparation of transforming growth factor-beta (T GF-beta)-resistant cytotoxic Tlymphocytes (CTL) reactive to Epstein-Barr virus (EBV) latent membrane proteins 1 and 2 (LMP 1 and 2) with potential antineoplastic activity. T lymphocytes are transduced with a retroviral vector expressing the dominant-negative mutant type II T GF-beta receptor, which blocks signaling by all three T GF-beta isoforms. These T GF-beta-resistant Tlymphocytes are exposed ex-vivo to dendritic cells (DCs) transfected with a replicationdeficient adenovirus encoding EBV LMP; subsequent exposure to LMP1- or LMP2expressing lymphoblastoid cell lines is used to expand the CTL. Administered to patients with EBV-positive tumors, T GF-beta-resistant LMP-specific CT L target LMP-positive cells, which may result in a specific CTL response, followed by cell lysis and inhibition of tumor cell proliferation. Tumor-expressed T GF-beta inhibits T lymphocyte activation and expansion. 